九州大学学術情報リポジトリ

Kyushu University Institutional Repository

\title{
Comparative Analysis on Influence Factors of Urban Vegetable Production in China : Based on Data of Beijing, Shanghai and Hangzhou
}

Zhao, Xia

Department of Agricultural Economics, College of Economics and Management, China Agricultural University

Mu, Yueying

Department of Agricultural Economics, College of Economics and Management, China Agricultural University

Ito, Shoichi

International Food Policy Economist, Faculty of Agriculture, Kyushu University

https://doi.org/10.5109/22091

出版情報: 九州大学大学院農学研究院紀要. 57 (1)，pp.353-363，2012-02. Faculty of Agriculture， Kyushu University

バージョン :

権利関係 : 


\title{
Comparative Analysis on Influence Factors of Urban Vegetable Production in China —Based on Data of Beijing, Shanghai and Hangzhou
}

\author{
${\mathrm{Xia} \mathrm{ZHAO}^{1 *} \text {, Yueying } \mathrm{MU}^{1} \text { and Shoichi ITO }}^{2}$ \\ ${ }^{1}$ Department of Agricultural Economics, College of Economics and Management, China Agricultural University, \\ No.17, Qinghuadong Road, Beijing 100083, P. R. China \\ ${ }^{2}$ International Food Policy Economist, Faculty of Agriculture, Kyushu University, \\ Fukuoka 812-8581, Japan \\ (Received October 31, 2011 and accepted November 9, 2011)
}

\begin{abstract}
To guarantee the safety of metropolitan cities' vegetable supply is not only the important basis of economic development and social stability, but also a key part of the national food security strategy in China. Based on the practical data of Beijing, Shanghai and Hangzhou, this paper employs grey correlation dynamic analysis (hereafter GCDA) method to comparatively analyze the influence factors that impact the three cities' vegetable production in the natural, technical, and economic aspects, such as vegetable sown areas, yearly rainfall, average air temperature, sunshine hours, yield per area, effective irrigation areas, total agricultural machinery power, rural electrical power consumption, amount of chemical fertilizer consumption, total costs of unit vegetable production, net profits of unit vegetable production, labor number, urbanization and industrial development levels. The analysis results show that different factors have different influences on the vegetable production for the metropolitan cities in different regions. Especially, the following factors, such as the vegetable sown areas, total power of agricultural machinery, reasonable fertilizer consumption, effective irrigating areas, and sufficient labor number, have higher impacts on the vegetable production capability of the three major cities compared with other factors. In the end of this paper, the different countermeasures for the different metropolitan cities are put forward according to the analysis results.
\end{abstract}

Key words: Comparative Analysis, GCDA Method, Influence Factors, Metropolitan Cities, Vegetable Production

\section{INTRODUCTION}

China is a country of mass vegetable production and consumption, with 30 percent of the world's total vegetable production. As one of essentials in people's daily lives, the supply of vegetables has distinctive features, such as long production cycle, being seasonal, lack of alternative products, short storage time, high demand of storage condition, high rate of loss and difficult to transfer the products, etc., so as to the vegetable supply needs more focus on timeliness and security of supply when compared with other necessities. In recent years, the security issues of urban vegetable supply become more and more important, with the increasingly outstanding problems of lack of adequate circulation and distribution facilities, frequent natural disasters and price fluctuation of vegetables. The State Council of China specially held an executive meeting on August 18, 2010 to study and plan to further promote vegetable production, and to ensure the basic stability of market supply and price policy measures, which raised the requirements of stabilizing and improving the capacity of the vegetable self-sufficient supply in particular for

- This paper is supported by Fruit Vegetables Industry Technology System of Beijing Innovation Team.

Department of Agricultural Economics, College of Economics and Management, China Agricultural University, P. R.China

International Food Policy Economist, Faculty of Agriculture, Kyushu University, Japan

* ZHAO, Xia is co-corresponding authors (E-mail: zhaoxia_ pku@yahoo.com.cn) metropolitan cities with more than millions of people in the urban areas. In China's most famous cities such as Beijing, Shanghai, Hangzhou, it is especially important and urgent to ensure a degree of self-sufficient supply capacity and security of vegetable supply.

Previous researches for the Chinese vegetables mainly focused on the following aspects: First, studies from the perspective of vegetable supply chain (Yang, 2006; LU, et al., 2009; Lee and Zhou, 2009; Shao, 2009; $\mathrm{Wu}$, 2009, Zang, 2009), started from the local or national level, evaluated existing vegetable supply chain, and set up a series of analysis on how to build a more perfect vegetable supply chain, optimize the supply chain structure and other aspects. Second, studies from the perspectives of vegetable production, consumption, processing, distribution, foreign trade and other angles (Wang, 2004; Xiao, 2007; Lee, 2006; Liu, 2005; Wang, 2007; Zheng, 2005; Lee, 2006), explored the effects of different influencing factors on the vegetable industry and put forward suggestions and countermeasures on improving the international competitiveness of China's vegetable industry in the future. Third, studies from the perspective of price changes (Zhao et al., 2010; Pan and $\mathrm{Mu}, 2010$ ), made a systematic analysis of trends and causes of vegetable price changes in different parts. Fourth, studies from the perspectives of vegetable industry development and modes of market organization (Yang, 2004; Feng, 2004; Kou, 2004), analyzed the problems of the vegetable industry are facing and put forward the countermeasures in the end. Fifth, studies from the perspectives of vegetable supply security of 
quality and quantity (He, 2007; Zhao and Zhang, 2008; Zhao, 2009; Chen, et al., 2009), analyzed the quality and quantity of vegetable supply condition in different provinces, and made corresponding countermeasures on the future security of vegetable supply.

The studies above are of importance for this paper. From the perspective of research, however, most of the papers analyzed issues such as vegetable supply chain, vegetable trade, vegetable industry and vegetable prices, while the researches on the production and safe supply of vegetables in China's major cities are still not indepth. Although some documents are related to the safe supply of urban vegetable production, there is still a lack of systematic quantitative analysis, less typical cities selected, a lack of comparative analysis on security situations among the cities and defects. Therefore, this paper tries to make up these gaps above, selects Beijing, Shanghai and Hangzhou as study areas, fully thinks the various factors which influence the capacity of vegetable production, such as natural conditions, technical level and economic factors, and initially takes the GCDA method to compare and analyze different roles of these factors on vegetable production in different regions of the Chinese cities, and then puts forward the countermeasures. In the current background of declining trend in production and self-sufficient supply rate, increasing ups and downs trend of vegetable prices and increasingly prominent problems of urban vegetable's safe supply, this study has positive significance for the stability of vegetable production and security protection of supply in Chinese metropolitan cities.

\section{MATERIALS AND METHODS}

\section{Basic Idea}

The basic idea of this paper is as follows: first to make a statistical comparative analysis of vegetable industry development trend in the three metropolitan cities: Beijing, Shanghai and Hangzhou; second to tease out possible factors influencing urban vegetable production, and make use of GCDA method to explore the dynamic relationship between various factors and vegetable production of the three major cities since 2000; third to find out the effects that these factors have affected differently on the three cities' vegetable production; and finally to take the outcomes of data analysis and characteristics of different metropolitan cities above into account, the measurements are given to promote Chinese metropolitan cities' vegetable production rate. Some suggestions for further studies are discussed in the end.

\section{Index system construction}

The capacity of urban vegetable production can be influenced by some factors. These influence factors are described in figure 1.

Natural conditions factors mainly include the sown areas of vegetables, yearly rainfall, average air temperature, hours of sunshine, etc.. The sown areas directly determine the outputs level of urban vegetable. Yearly rainfall, average air temperature and hours of sunshine have a direct impact on vegetable varieties, qualities and output levels.

Technical factors include yield per unit area, irrigated areas, total agricultural machinery power, electrical power consumption and amount of chemical fertilizer. The level of technology represents the level of agricultural modernization, and it also affects the vegetables' quality and yield. While the level of yield per unit area represents the level of vegetables' cultivation technology and has a direct impact on vegetable production. For the irrigated areas, even if the yearly rainfall is insufficient, as long as there are efficient irrigation equipments to irrigate the vegetable plots, in the case of electrical power guaranteed, there still would be higher outputs. Combined with effective fertilization, total agricultural machinery power helps improve the ability to keep the soil moisture and form a favorable environment for vegetables' growth, and as a result the outputs of vegetable can be improved. Meanwhile, total agricultural machinery power applied in circulation field can effectively improve the efficiency of vegetables' sales and other aspects, which plays a positive role in promoting vegetables' industry development.

Economic factors include the total costs per unit area of vegetable production, net profits per unit area of vegetable production, labor number per unit area of vegetable production, urbanization rate and industrial development level etc.. Here, the first three factors directly affect the vegetables' cultivation and the vege-

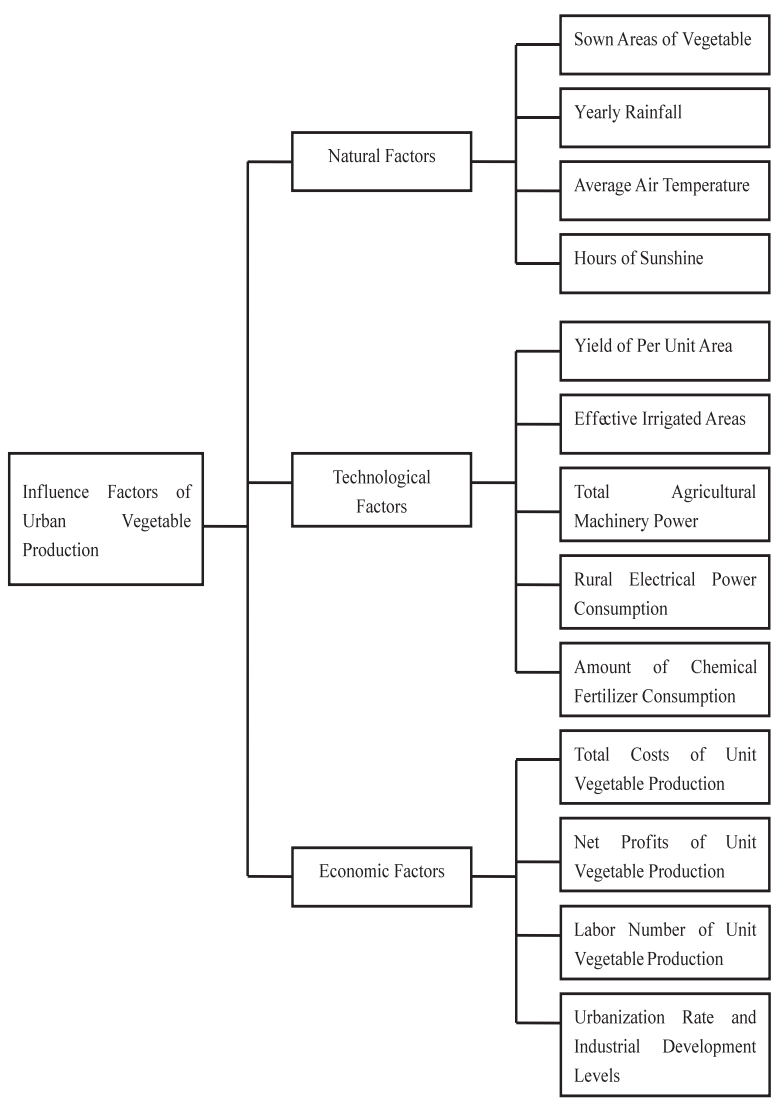

Fig. 1. Influence Factors of Urban Vegetable Production. 
table outputs. The lower of the cost, the fewer of labor numbers and the higher of the profit can effectively improve the vegetable outputs. On the other hand, the vegetable outputs would be lower. In addition, under the condition of limited land resources, with the metropolitan cities' industrialization, urbanization and the rapid development process of the secondary and tertiary economic sectors, the areas of vegetable planting are increasingly declined, and more human resources are swarming into the secondary and tertiary industries, which to some extent are not conducive to the development of urban vegetable production. This study adopts the proportion of the total value of agricultural outputs to GDP to reflect the gradually weakened proportion of the agricultural economy in the national economy and the possible impacts on urban vegetable production caused by the rapid development of the secondary and tertiary industries.

In addition, the policy factors such as government subsidies, supporting policies etc. should play a positive role on promoting the development of vegetables' industry. However, there factors are not considered in this paper in view of without accurate data. The policy factors will be researched in another paper based on spots investigation.

\section{Methodology}

The GCDA method is adopted in the paper, which was formulated by Deng (1982). In the grey system theory, completely information in a system is defined as a white system. On the contrary, nobody can obtain any information and system characteristics which are in black system. Then the grey system is situated between the two systems above. "The minimal data requirement, simplicity of use and reasonable expected results are the advantages of the grey system over the traditional regression analysis." ${ }^{3}$ GCDA method can be used to distinguish which are the primary factors, and which are the secondary factors within an imperfect information system, and the statistical tests are not necessary using this method. Now, it has been widely approached by dozens of scholars from diverse research perspectives, such as energy-related studies (Morita, et al., 1996; Lu, et al., 2008), agriculture field (Wang, et al., 2010; Huang, et al., 2007), economics field (Hamzacebi and Pekkaya, 2011; Zhao, et al., 2011), management field (Sun, et al., 2007; Lin, 2003), etc.. The basic procedures of GCDA method generally include the following steps.

\section{Step 1: Defining data}

Let $x_{0}$ be the grey relational set, it is called mothersequence with m entries, $x_{0}=\left(x_{0}(1), x_{0}(2), \ldots, x_{0}(m)\right)^{T}$. Let $x_{i}$ be the $i^{\text {th }}$ sub-sequence, $x_{i}=\left(x_{i}(1), x_{i}(2), \ldots\right.$, $\left.x_{i}(m)\right)^{T}$, where $i=1,2, \ldots, n$, and $n$ represents the number of sub-sequences. The correction coefficient is calculated between $x_{0}$ and $x_{i}$ in the end. In this paper, the vegetable production in different metropolitan cities is the mother-sequence, and the different influence fac- tors are the sub-sequences

Step 2: Normalizing the raw data

In this step, the raw data are normalized to eliminate the dimensional influence. The normalization method is given as follows:

$$
y_{0}=\frac{x_{0}(k)}{x_{0}(1)}, y_{j}=\frac{x_{i}(k)}{x_{i}(1)}
$$

Where $i=1,2, \ldots, n ; k=1,2, \ldots, m ; y_{0}$ is the normalized mother-sequence, and $y_{i}$ is the normalized subsequences.

Step 3: Calculating the grey correlation coefficient

The grey correlation coefficient $\zeta_{0 i}(k)$ of the normalized sub-sequences $y_{i}(t)$ is to the normalized mother-sequence $y_{0}(t)$ at the time $\mathrm{t}=\mathrm{k}$ can be expressed as the following formula:

$$
\zeta_{o i}(k)=\frac{\min _{i} \min _{k}\left|y_{0}(k)-y_{i}(k)\right|+\rho \max _{i} \max _{k}\left|y_{0}(k)-y_{i}(k)\right|}{\left|y_{0}(k)-y_{i}(k)\right|+\rho \max _{i} \max _{k}\left|y_{0}(k)-y_{i}(k)\right|}
$$

Where $\rho$ is the distinguishing coefficient used to adjust the difference of the correlation coefficient, usually $\rho=\in(0,1)$ (Deng, 1989). According to the sensitivity analysis, $\rho=0.5$ is a good choice which can due to the moderate distinguishing effects and good stability of outcomes (Lu, et al., 2008). Therefore, $\rho=0.5$ is adopted in the following calculation in this paper.

Step 4: Calculating the grey correlation grade

Grey correlation grades for $y_{0}(t)$ and $y_{i}(t)$ are given by the average of the grey correlation coefficients as

$$
\zeta_{o i}=\frac{1}{n} \sum_{k=1}^{n} \zeta_{0 i}(k)_{i}
$$

\section{Step 5: Ranking the grey correlation grade}

In this step, the order of the grey correlation grades is ranked according to their values. The higher values of the grey correlation grades are, the higher influence degree of the sub-sequences affect on the mothersequence.

Step 6: Calculating the dynamic grey correlation grade

In this step, the grey correlation grades based on different base year are calculated repeatedly to show the dynamic changing trends with the time varying and avoid the possible contingency in a particular year. Then the ultimate dynamic grey correlation grades are calculated by the average of the grey correlation grades based on different base year.

\section{RESULTS}

\section{General Statistical Analysis}

The general statistical analysis is firstly done before the GCDA to compare and analyze the changing situation of vegetable production in different metropolitan 
Table 1. Vegetable Production in the Three Major Cities since 2000

\begin{tabular}{|c|c|c|c|c|c|c|c|c|c|c|c|}
\hline & Indicators & 2000 & 2001 & 2002 & 2003 & 2004 & 2005 & 2006 & 2007 & 2008 & 2009 \\
\hline \multirow{7}{*}{ Beijing } & Sown Areas $\left(\mathrm{k} \cdot \mathrm{km}^{2}\right)$ & 1040.00 & 1130.00 & 1150.00 & 1080.00 & 910.00 & 790.00 & 710.00 & 700.00 & 680.00 & 680.00 \\
\hline & Vegetable Outputs (M.kg) & 4663.00 & 4910.00 & 5074.00 & 4867.00 & 4441.00 & 3731.00 & 3412.00 & 3401.00 & 3213.00 & 3171.00 \\
\hline & Yield Per Unit Area $\left(\mathrm{kg} / \mathrm{km}^{2}\right)$ & 4484.00 & 4345.00 & 4412.00 & 4506.00 & 4880.00 & 4723.00 & 4806.00 & 4859.00 & 4725.00 & 4663.00 \\
\hline & $\begin{array}{l}\text { Per Capita Vegetable } \\
\text { Production (kg) }\end{array}$ & 341.96 & 354.49 & 356.52 & 334.18 & 297.51 & 242.59 & 215.81 & 208.27 & 189.56 & 180.68 \\
\hline & $\begin{array}{l}\text { Vegetable Output Values } \\
\text { (million yuan) }\end{array}$ & 5188.70 & 4434.82 & 4973.18 & 4854.71 & 4432.79 & 4617.13 & 4325.49 & 4063.79 & 4233.90 & 5335.37 \\
\hline & $\begin{array}{l}\text { Proportion of Sown Areas to } \\
\text { Total Agricultural Sown Areas } \\
\text { (\%) }\end{array}$ & 22.91 & 29.74 & 34.33 & 35.88 & 29.93 & 25.65 & 22.19 & 23.73 & 21.12 & 21.25 \\
\hline & $\begin{array}{l}\text { Proportion of Vegetable } \\
\text { Output Value to Agricultural } \\
\text { Output Values (\%) }\end{array}$ & 56.96 & 53.08 & 56.10 & 59.02 & 53.47 & 49.72 & 43.19 & 42.38 & 39.07 & 39.31 \\
\hline \multirow{5}{*}{ Shanghai } & Sown Areas $\left(\mathrm{k} \cdot \mathrm{km}^{2}\right)$ & 1400.00 & 1494.00 & 1607.00 & 1504.00 & 1399.00 & 1309.00 & 1362.00 & 1339.00 & 1336.00 & 1282.00 \\
\hline & Vegetable Outputs (M.kg) & 3770.00 & 4240.40 & 4766.00 & 4605.40 & 4366.50 & 4090.30 & 4187.60 & 4134.90 & 4099.90 & 3940.80 \\
\hline & Yield Per Unit Area $\left(\mathrm{kg} / \mathrm{km}^{2}\right)$ & 2693.00 & 2838.00 & 2966.00 & 3062.00 & 3121.00 & 3125.00 & 3075.00 & 3088.00 & 3069.00 & 3074.00 \\
\hline & $\begin{array}{l}\text { Per Capita Vegetable } \\
\text { Production (kg) }\end{array}$ & 234.36 & 262.73 & 293.29 & 269.16 & 250.66 & 230.00 & 230.71 & 222.54 & 217.10 & 205.11 \\
\hline & $\begin{array}{l}\text { Proportion of Sown Areas to } \\
\text { Total Agricultural Sown Areas } \\
\text { (\%) }\end{array}$ & 26.85 & 30.43 & 33.71 & 35.88 & 34.59 & 32.43 & 33.93 & 34.27 & 34.40 & 32.37 \\
\hline \multirow{7}{*}{ Hangzhou } & Sown Areas $\left(\mathrm{k} \cdot \mathrm{km}^{2}\right)$ & 863.00 & 889.00 & 1023.00 & 1021.00 & 1041.00 & 1031.00 & 1017.00 & 1070.00 & 1027.00 & 989.00 \\
\hline & Vegetable Outputs (M.kg) & 2360.50 & 2490.80 & 2675.80 & 2882.80 & 3010.30 & 3093.20 & 3144.00 & 3278.20 & 3236.10 & 3133.50 \\
\hline & Yield Per Unit Area $\left(\mathrm{kg} / \mathrm{km}^{2}\right)$ & 2736.00 & 2803.00 & 2617.00 & 2822.00 & 2891.00 & 3002.00 & 3092.00 & 3065.00 & 3151.00 & 3167.00 \\
\hline & $\begin{array}{l}\text { Per Capita Vegetable } \\
\text { Production (kg) }\end{array}$ & 379.76 & 395.90 & 420.19 & 448.49 & 461.92 & 468.35 & 471.85 & 487.58 & 477.56 & 458.54 \\
\hline & $\begin{array}{l}\text { Vegetable Output Values } \\
\text { (million yuan) }\end{array}$ & 3035.83 & 3330.16 & 3403.08 & 3512.06 & 2956.71 & 3545.68 & 3811.84 & 4048.75 & 4296.70 & 4650.40 \\
\hline & $\begin{array}{l}\text { Proportion of Sown Areas to } \\
\text { Total Agricultural Sown Areas } \\
\text { (\%) }\end{array}$ & 19.19 & 20.84 & 24.91 & 26.03 & 26.14 & 25.93 & 26.10 & 27.10 & 25.45 & 24.96 \\
\hline & $\begin{array}{l}\text { Proportion of Vegetable } \\
\text { Output Value to Agricultural } \\
\text { Output Value (\%) }\end{array}$ & 33.61 & 34.06 & 35.75 & 34.96 & 29.74 & 31.48 & 31.25 & 31.78 & 31.75 & 30.38 \\
\hline
\end{tabular}

Data sources: 2001-2010 Beijing Statistical Yearbook, Shanghai Statistical Yearbook, Hangzhou Statistical Yearbook, and China Statistical Yearbook. Also, the data of vegetable output values in the table are excluded the factors of price changes based on the 2000; the data of proportion is calculated according to the raw data in the table 1 ; and the production of vegetables per capita is calculated from vegetable output divided by the resident population of the city. Additionally, with the lack of data of total vegetable output values in the Shanghai Statistical Yearbook, it's not shown in the table.

cities such as Beijing, Shanghai and Hangzhou in recent years, so as to find out the actual situations of vegetable production in the three cities, which lays the foundation for the further analysis.

The indicators, such as areas, yield, outputs and other indicators created by the proportion of the total number are used to compare and judge a city's level of vegetable production (data shown in Table1).

The comparison results can be seen from figure 2 , 3 , and 4. Overall, Beijing's moving trend of vegetable production is the least optimistic. According to the indicators like the sown areas and its proportion, per capita vegetable production, vegetable output values and the proportion of total agricultural output value and so on, Beijing has shown a downward trend in recent years. However, according to the indicator of the yield per unit area, the level in Beijing is much higher than that of Shanghai or Hangzhou, showing an obvious advantage. Compared with Beijing, the trend of vegetable production in Shanghai moves slowly with a gradual decline. The capacity of vegetable production in Hangzhou is the most stable, with the highest level per capita vegetable production, and the strongest ability of vegetables' comprehensive production.

It can be seen that the capacities of vegetable production of Beijing, Shanghai and Hangzhou are different through the comparison above. Now we consider what factors on earth affect urban capacities of vegetable production? This part mainly do a systematic analysis by GCPA method and a comparative analysis on the influence factors of urban capacities of vegetable production, and then find out the main reasons that result 


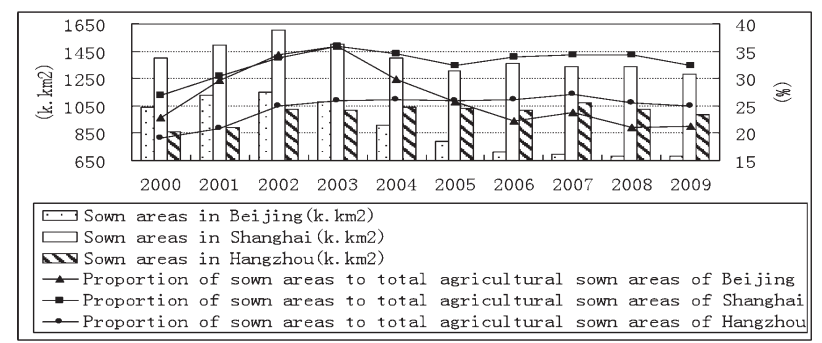

Fig. 2. Vegetable Sown Areas and Proportion in the Three Major Cities.

Data sources: derived from Table 1

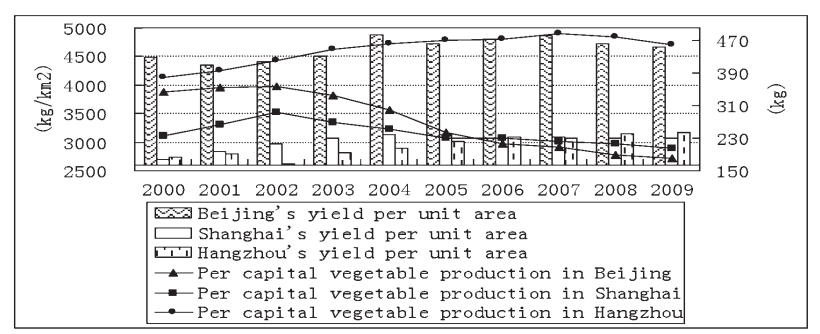

Fig. 3. Yields and Per Capita Production of Vegetable in the Three Major Cities.

Data sources: derived from Table 1

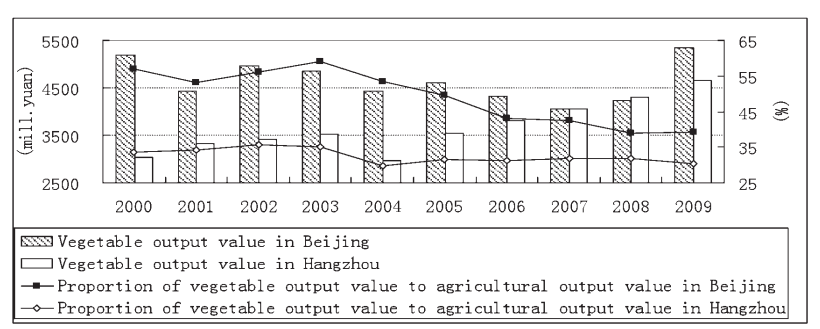

Fig. 4. Vegetable Output Value and Proportion of Beijing and Hangzhou.

Data sources: derived from Table 1

in the uneven capacities of vegetable production of the three metropolitan cities.

\section{Impact Analysis of Various Factors on the Capacity of Vegetable production in Beijing}

The dynamic correlation grades of the influence factors on the vegetable output of Beijing are obtained through the GCDA, which represent the relative influence degrees of the factors to Beijing vegetable output. (Data are shown in table 2 and 3). According to the descending order, the order of the dynamic correlation grades is: vegetables' sown areas $>$ total agricultural machinery power $>$ the proportion of agriculture output value to GDP > labor number per unit > the amount of fertilizer consumption $>$ the effective irrigated area $>$ sunshine hours $>$ electrical power consumption $>$ average air temperature $>$ yield per unit area $>$ yearly rain- fall $>$ total costs per unit area of vegetable production $>$ net profits per unit area of vegetable production.

For more detail, the first factor is the vegetable sown areas, it has the highest grey correlation grade (0.95) to the vegetable outputs, which indicates that the capacity of Beijing's vegetable production depends on the amount of vegetables' sown areas to the maximum extent. The second factors is the total power of agricultural machinery (the grey correlation grade is 0.88 ), which means that high level of agricultural machinery can promote vegetable production. The third factor which affects the vegetable production is the proportion of agriculture output values to GDP (the grey correlation grade is 0.86). With the status of agricultural economy in the national economy gradually weakened, and the rapid development process of industrialization, urbanization and the service industry meanwhile, the lands used for vegetables planting before are now used for industrial development, real estate and other service projects. This development trend negatively affects vegetables production and the self-sufficient supply capacity in Beijing in a large extent. The fourth factor is labor number per unit area of vegetable production (the grey correlation grade is 0.84 ). With the rapid development of non-agricultural industries, a great number of human capitals pour into the secondary and tertiary industry. As a result, the number and quality of labor power engaged in vegetable production are decreasing year by year. This situation is not conducive to vegetable production in Beijing. The fifth factor is the amount of fertilizer consumption (the grey correlation grade is 0.81 ), and the sixth factor is the effective irrigated areas (the grey correlation grade is $0.81^{4}$ ), which reflect that the technology level plays a positive role in the vegetable production in Beijing. Appropriate amount of fertilizer consumption and effective irrigation areas contribute to the increasing of vegetable production in Beijing.

Other factors, such as sunshine hours, electrical power consumption, average air temperature, yield per unit area, have relatively secondary impacts on the vegetable production capability compared with the factors above. As for the sunshine hours and the average air temperature factors, both have a certain influence on Beijing vegetables planting. Sunshine duration and the average air temperatures influence the quality and output of vegetables to a large extent. However, there is longer duration of sunshine while lower average air temperature compared with the other two cities, so it's a common way to plant vegetables taking greenhouse facilities in Beijing. That might be the reason that to some extent decreases the impact degree of average air temperatures on Beijing's vegetable production. For the factor of yield per unit area, its effects on promoting vegetables production is too limited in Beijing, because the extremely scarce land resources has already result-

The grey correlation grade between the effective irrigated areas and the vegetable outputs in Beijing is 0.8078 if it keeps four figures after the decimal point, which is a little bit below the grey correlation grade between the amount of fertilizer consumption and the vegetable outputs in Beijing, so as to the effective irrigated areas is the sixth impact factors, behind the amount of fertilizer consumption. 
ing sharp drop in vegetable acreage. The reason which resulting the weak correlation of rural electrical power consumption and vegetable production may be that: much electrical power is consumed in the secondary and tertiary industries which located in Beijing rural areas. This situation leads to the role of this index on vegetable production is relatively weak.

Rainfall, total costs per unit and net profits per unit have lower grey correlation grade values with Beijing's vegetable production compared with the impact factors above. For the rainfall factor, the lower grey correlation grade vale with the vegetable production is not a bad thing, which means that the amount of rainfall in Beijing is no longer an important restricting factors in vegetable production, with the continuous increases in China's national and local financial resources for investment in irrigation and water conservancy facilities. As for the two factors of total costs per unit and net profits per unit, it is an unexpected result that the both grey correlation grade values with Beijing's vegetable production are not very high, which means the impacts of the both factors are not very strong to Beijing's vegetable

Table 2. Influence Factors on Vegetable Production in the Three Major Cities since 2000

\begin{tabular}{|c|c|c|c|c|c|c|c|c|c|c|c|c|c|c|c|}
\hline Cities & Year & $\begin{array}{c}\text { Vegetable } \\
\text { Outputs } \\
\text { (M.kg) }\end{array}$ & $\begin{array}{c}\text { Sown } \\
\text { Areas of } \\
\text { Vegetable } \\
\left(\mathrm{k} . \mathrm{km}^{2}\right)\end{array}$ & $\begin{array}{c}\text { Yearly } \\
\text { Rainfall } \\
\text { (m.m) }\end{array}$ & $\begin{array}{l}\text { Average Air } \\
\text { Temperature } \\
\quad\left({ }^{\circ} \mathrm{C}\right)\end{array}$ & $\begin{array}{c}\text { Hours of } \\
\text { Sunshine } \\
(\mathrm{ks})\end{array}$ & $\begin{array}{c}\text { Yield Per } \\
\text { Unit Area } \\
\left(\mathrm{kg} . / \mathrm{km}^{2}\right)\end{array}$ & $\begin{array}{l}\text { Effective } \\
\text { Irrigated } \\
\text { Areas } \\
\left(\mathrm{k} \cdot \mathrm{km}^{2}\right)\end{array}$ & $\begin{array}{c}\text { Total } \\
\text { Agricultural } \\
\text { Machinery } \\
\text { Power } \\
\text { (MW) }\end{array}$ & $\begin{array}{c}\text { Electrical } \\
\text { Power } \\
\text { Consumption } \\
(\mathrm{GW} / \mathrm{s})\end{array}$ & $\begin{array}{l}\text { Amount of } \\
\text { Chemical } \\
\text { Fertilizer } \\
\text { Consumption } \\
\text { (M.kg) }\end{array}$ & $\begin{array}{l}\text { Total } \\
\text { Costs } \\
\text { Per Unit } \\
\text { (yuan/ } \\
\mathrm{km}^{2} \text { ) }\end{array}$ & $\begin{array}{c}\text { Net } \\
\text { Profits } \\
\text { Per Unit } \\
\text { (yuan/ } \\
\mathrm{km}^{2} \text { ) }\end{array}$ & $\begin{array}{c}\text { Labor } \\
\text { Number } \\
\left(\mathrm{ks} / \mathrm{km}^{2}\right)\end{array}$ & $\begin{array}{c}\text { Proportion } \\
\text { of } \\
\text { Agricultural } \\
\text { Output } \\
\text { Value to } \\
\text { GDP (\%) }\end{array}$ \\
\hline \multirow{10}{*}{ Beijing } & 2000 & 4663.00 & 1040.00 & 371.10 & 12.80 & 160.03 & 4484.00 & 3227.00 & 3992.00 & 95.38 & 179.00 & 8.50 & 7.41 & 0.45 & 2.51 \\
\hline & 2001 & 4910.00 & 1130.00 & 338.90 & 12.90 & 156.70 & 4345.00 & 3227.00 & 3949.00 & 103.30 & 157.00 & 8.59 & 9.20 & 0.43 & 2.18 \\
\hline & 2002 & 5074.00 & 1150.00 & 370.40 & 13.20 & 155.30 & 4412.00 & 2197.00 & 3818.00 & 69.04 & 149.00 & 8.56 & 7.88 & 0.42 & 1.91 \\
\hline & 2003 & 4867.00 & 1080.00 & 444.90 & 12.90 & 135.61 & 4506.00 & 1789.00 & 3669.00 & 71.21 & 143.00 & 8.74 & 8.94 & 0.42 & 1.68 \\
\hline & 2004 & 4441.00 & 910.00 & 483.50 & 13.50 & 150.92 & 4880.00 & 1867.00 & 3403.00 & 63.99 & 145.00 & 11.75 & 10.42 & 0.49 & 1.45 \\
\hline & 2005 & 3731.00 & 790.00 & 410.70 & 13.20 & 154.57 & 4723.00 & 1815.00 & 3377.00 & 70.28 & 148.00 & 11.63 & 10.71 & 0.44 & 1.27 \\
\hline & 2006 & 3412.00 & 710.00 & 318.00 & 13.40 & 131.56 & 4806.00 & 1815.00 & 3255.00 & 69.41 & 148.40 & 13.16 & 10.07 & 0.42 & 1.09 \\
\hline & 2007 & 3401.00 & 700.00 & 483.90 & 14.00 & 141.07 & 4859.00 & 1736.00 & 3005.00 & 68.54 & 139.90 & 14.02 & 14.85 & 0.41 & 1.03 \\
\hline & 2008 & 3213.00 & 680.00 & 626.30 & 13.40 & 143.48 & 4725.00 & 1718.00 & 2670.00 & 71.23 & 136.00 & 14.77 & 12.55 & 0.37 & 1.01 \\
\hline & 2009 & 3171.00 & 680.00 & 480.60 & 13.30 & 150.71 & 4663.00 & 1652.00 & 2715.00 & 73.18 & 138.00 & 15.40 & 13.92 & 0.37 & 0.97 \\
\hline \multirow{10}{*}{ Shanghai } & 2000 & 3770.00 & 1400.00 & 1331.70 & 17.20 & 98.97 & 2693.00 & 2859.00 & 1425.00 & 121.98 & 193.30 & 8.50 & 7.41 & 0.45 & 1.61 \\
\hline & 2001 & 4240.40 & 1494.00 & 1276.80 & 17.20 & 114.89 & 2838.00 & 2806.00 & 1339.20 & 132.77 & 202.80 & 8.59 & 9.20 & 0.43 & 1.50 \\
\hline & 2002 & 4766.00 & 1607.00 & 1435.40 & 17.50 & 106.80 & 2966.00 & 2704.00 & 1268.70 & 136.32 & 176.80 & 8.56 & 7.88 & 0.42 & 1.39 \\
\hline & 2003 & 4605.40 & 1504.00 & 756.90 & 17.00 & 102.84 & 3062.00 & 2573.00 & 1126.10 & 149.50 & 158.70 & 8.74 & 8.94 & 0.42 & 1.21 \\
\hline & 2004 & 4366.50 & 1399.00 & 1158.10 & 18.10 & 115.78 & 3121.00 & 2457.00 & 1051.50 & 190.58 & 150.20 & 11.75 & 10.42 & 0.49 & 1.03 \\
\hline & 2005 & 4090.30 & 1309.00 & 1254.90 & 17.50 & 106.70 & 3125.00 & 2373.00 & 964.60 & 207.55 & 144.40 & 11.63 & 10.71 & 0.44 & 0.98 \\
\hline & 2006 & 4187.60 & 1362.00 & 1042.60 & 18.40 & 98.29 & 3075.00 & - & 972.30 & 239.23 & 145.30 & 13.16 & 10.07 & 0.42 & 0.89 \\
\hline & 2007 & 4134.90 & 1339.00 & 1208.80 & 18.50 & 85.00 & 3088.00 & 2061.00 & 976.80 & 286.13 & 140.80 & 14.02 & 14.85 & 0.41 & 0.82 \\
\hline & 2008 & 4099.90 & 1336.00 & 1512.80 & 17.50 & 92.08 & 3069.00 & 2345.00 & 945.10 & 296.75 & 143.20 & 14.77 & 12.55 & 0.37 & 0.79 \\
\hline & 2009 & 3940.80 & 1282.00 & 1457.90 & 17.80 & 90.39 & 3074.00 & 2023.00 & 992.30 & 319.67 & 125.60 & 15.40 & 13.92 & 0.37 & 0.76 \\
\hline \multirow{10}{*}{ Hangzhou } & 2000 & 2360.50 & 863.00 & 1198.30 & 17.20 & 90.83 & 2736.00 & 1708.10 & 2664.20 & 62.98 & 111.30 & 8.50 & 7.41 & 0.45 & 7.52 \\
\hline & 2001 & 2490.80 & 889.00 & 1566.60 & 17.30 & 99.86 & 2803.00 & 1699.00 & 2683.10 & 73.17 & 120.20 & 8.59 & 9.20 & 0.43 & 7.11 \\
\hline & 2002 & 2675.80 & 1023.00 & 1744.00 & 17.50 & 87.28 & 2617.00 & 1680.50 & 2786.30 & 91.31 & 129.20 & 8.56 & 7.88 & 0.42 & 6.43 \\
\hline & 2003 & 2882.80 & 1021.00 & 948.90 & 17.50 & 103.57 & 2822.00 & 1768.10 & 2808.10 & 113.23 & 129.60 & 8.74 & 8.94 & 0.42 & 6.03 \\
\hline & 2004 & 3010.30 & 1041.00 & 1046.50 & 17.80 & 112.49 & 2891.00 & 1664.50 & 2875.30 & 109.97 & 130.90 & 11.75 & 10.42 & 0.49 & 5.20 \\
\hline & 2005 & 3093.20 & 1031.00 & 1138.60 & 17.50 & 105.73 & 3002.00 & 1654.10 & 2972.80 & 127.77 & 130.50 & 11.63 & 10.71 & 0.44 & 5.04 \\
\hline & 2006 & 3144.00 & 1017.00 & 1164.30 & 18.30 & 85.37 & 3092.00 & 1759.40 & 3008.40 & 142.31 & 130.20 & 13.16 & 10.07 & 0.42 & 4.50 \\
\hline & 2007 & 3278.20 & 1070.00 & 1378.50 & 18.40 & 88.37 & 3065.00 & 1726.60 & 3097.70 & 159.62 & 130.40 & 14.02 & 14.85 & 0.41 & 3.99 \\
\hline & 2008 & 3236.10 & 1027.00 & 1273.90 & 17.50 & 98.47 & 3151.00 & 1726.40 & 3153.50 & 161.79 & 119.30 & 14.77 & 12.55 & 0.37 & 3.74 \\
\hline & 2009 & 3133.50 & 989.00 & 1615.90 & 17.80 & 102.59 & 3167.00 & 1726.40 & 3223.20 & 164.97 & 118.90 & 15.40 & 13.92 & 0.37 & 3.74 \\
\hline
\end{tabular}

Data Sources: Beijing Statistical Yearbook over the years, Shanghai Statistical Yearbook over the years, Hangzhou Statistical Yearbook over the years, and the National Agricultural Product Costs and Returns Compilation 2010. For more detail, about the three factors: total costs, net profits and labor numbers, we adopt the data in "Average Cost and Earnings of Vegetables in Major Cities" from "National Agricultural Costs and Returns Information" (2000-2010) 
Table 3. Influence Factors on Vegetable Production in the Three Major Cities since 2000

\begin{tabular}{|c|c|c|c|c|c|c|c|c|c|c|c|c|c|c|}
\hline $\begin{array}{c}\text { GCDA } \\
\text { Results }\end{array}$ & Cities & $\begin{array}{c}\text { Sown } \\
\text { Areas of } \\
\text { Vegetable }\end{array}$ & $\begin{array}{c}\text { Yearly } \\
\text { Rainfall }\end{array}$ & $\begin{array}{l}\text { Average Air } \\
\text { Temperature }\end{array}$ & $\begin{array}{l}\text { Hours of } \\
\text { Sunshine }\end{array}$ & $\begin{array}{l}\text { Yield Per } \\
\text { Unit Area }\end{array}$ & $\begin{array}{c}\text { Effective } \\
\text { Irrigated } \\
\text { Areas }\end{array}$ & $\begin{array}{c}\text { Total } \\
\text { Agricultural } \\
\text { Machinery } \\
\text { Power }\end{array}$ & $\begin{array}{c}\text { Electrical } \\
\text { Power } \\
\text { Consumption }\end{array}$ & $\begin{array}{c}\text { Amount of } \\
\text { Chemical } \\
\text { Fertilizer } \\
\text { Consumption }\end{array}$ & $\begin{array}{c}\text { Total } \\
\text { Costs } \\
\text { Per Unit }\end{array}$ & $\begin{array}{c}\text { Net } \\
\text { Profits } \\
\text { Per Unit }\end{array}$ & $\begin{array}{c}\text { Labor } \\
\text { Number } \\
\text { Per Unit }\end{array}$ & $\begin{array}{l}\text { Proportion } \\
\text { of } \\
\text { Agricultural } \\
\text { Output } \\
\text { Value to } \\
\text { GDP }\end{array}$ \\
\hline \multirow{3}{*}{$\begin{array}{c}\text { Dynamic } \\
\text { correlation } \\
\text { grade }\end{array}$} & Beijing & 0.95 & 0.65 & 0.77 & 0.79 & 0.76 & 0.81 & 0.88 & 0.78 & 0.81 & 0.62 & 0.61 & 0.84 & 0.86 \\
\hline & Shanghai & 0.95 & 0.76 & 0.89 & 0.86 & 0.90 & 0.88 & 0.88 & 0.59 & 0.88 & 0.67 & 0.70 & 0.85 & 0.76 \\
\hline & Hangzhou & 0.85 & 0.66 & 0.83 & 0.74 & 0.89 & 0.82 & 0.88 & 0.61 & 0.79 & 0.68 & 0.68 & 0.70 & 0.58 \\
\hline \multirow{3}{*}{$\begin{array}{c}\text { Order of } \\
\text { correlation } \\
\text { grade }\end{array}$} & Beijing & 1 & 11 & 9 & 7 & 10 & 6 & 2 & 8 & 5 & 12 & 13 & 4 & 3 \\
\hline & Shanghai & 1 & 9 & 3 & 7 & 2 & 5 & 6 & 13 & 4 & 12 & 11 & 8 & 10 \\
\hline & Hangzhou & 3 & 11 & 4 & 7 & 1 & 5 & 2 & 12 & 6 & 10 & 9 & 8 & 13 \\
\hline \multicolumn{15}{|c|}{$\begin{array}{l}\rho=0.5 \\
{ }^{1} \text { For Beijing data, the grey correlation grade between the effective irrigated areas and the vegetable outputs in Beijing is } 0.8078 \text { if it keeps four digits after the decimal point, which is a } \\
\text { little bit below the grey correlation grade between the amount of fertilizer consumption and the vegetable outputs in Beijing, so as to the effective irrigated areas is the sixth strongest } \\
\text { impact factors, less than the amount of chemical fertilizer consumption. For Shanghai data, the following three grey correlation grades: between amount of chemical fertilizer } \\
\text { consumption and the vegetable outputs in Shanghai, between effective irrigated areas and the vegetable outputs in Shanghai, and between total agricultural machinery power and the } \\
\text { vegetable outputs in Shanghai respectively are } 0.8771,0.8744 \text { and } 0.8732 \text { if they keep four digits after the decimal point, so the three impact factors orders of the dynamic correlation } \\
\text { grades are the amount of chemical fertilizer consumption > the effective irrigated areas }>\text { total agricultural machinery power. For Hangzhou data, the following two grey correlation } \\
\text { grades: between net profits and the vegetable outputs in Hangzhou, and between total costs and the vegetable outputs in Hangzhou respectively are } 0.6834 \text { and } 0.6825 \text { if they keep } \\
\text { four digits after the decimal point, so the two impact factors orders of the dynamic correlation grades are net profits }>\text { total costs. }\end{array}$} \\
\hline
\end{tabular}

production compared with other factors above. It seems that the results of the data analysis on the costs and profits per unit does not conform to the actual situation. This may be because the vegetable production in Beijing still are in extensive growth stage which mainly depend on increasing sown areas to extend their vegetable total outputs, so that the farmers in Beijing who plant vegetables may pay more attention to the annual total incomes than the costs and profits per unit, they might continue their vegetable planting and try to improve their total incomes through increasing the crop numbers and expanding the sown areas if possible, even though the costs and profits per unit are not so satisfied; or may because the costs and profits per unit factors have a lag impact on vegetable production, and these influences may be shown in the future years.

\section{Impact Analysis of Various Factors on the Capacity of Vegetable production in Shanghai}

The dynamic correlation grades of the influence factors on the vegetable outputs in Shanghai in table 3. According the descending order, the order of the dynamic correlation grades is: vegetables sown areas $>$ yield per unit area $>$ average air temperature $>$ the amount of fertilizer consumption $>$ the effective irrigated areas $>$ total agricultural machinery power $>$ sunshine hours $>$ the labor numbers per unit $>$ rainfall and the proportion of agriculture value to GDP $>$ net profits per unit> total costs per unit> electrical power consumption.

For more detail, first, vegetables sown areas and yield per unit area have the higher grey correlation grades to the vegetable outputs in Shanghai. These results are in line with the actual situation, since these two factors are very important to determine vegetable production in Shanghai. Second, the average air temperature also has a higher grey correlation grade value to the vegetables outputs in Shanghai. As a southern city, Shanghai's annual average air temperature maintains at about $17^{\circ} \mathrm{C}$, it is suitable for planting open field so as to there is very few greenhouse vegetable growing areas in Shanghai ${ }^{5}$. That might be the reason that the average air temperature has a very important influence on vegetables production in Shanghai. In the event of extreme weather, Shanghai vegetable production is largely affected. Third, the following three technical factors: effective irrigated areas, total power of agricultural machinery and fertilizer consumption have greater influence on vegetables production in Shanghai. Effective irrigated areas, efficient agricultural machinery and appropriate fertilizer consumption can conduce to the increase of vegetable production in Shanghai. Fourth, sunshine hours have a certain influence on the cultivation and output of vegetables in Shanghai. Sunshine duration has a significant impact on the quality and yield of vegetables. Fifth, the labor numbers per unit affect the vegetable production in Shanghai to a certain extent. Adequate labor power input is conducive to the improving of vegetable production; otherwise it will negatively affect the increase of vegetable production. With the rapid development of non-agricultural industries, a great number of human capitals pour into secondary and tertiary industries, as a result, the labor number and quality engaged in vegetable production

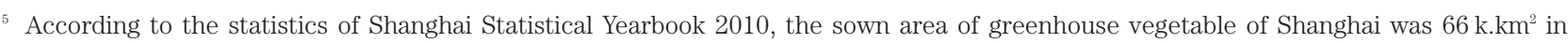
2009 , only $5.15 \%$ of the total vegetables sown area in that year. 
are decreasing year by year. This situation is not conducive to vegetable production capability in Shanghai. It's similar with Beijing.

Other factors, such as sunshine hours, the proportion of agriculture value to GDP, total costs per unit and net profits per unit, have limited influence on the vegetable production capability in Shanghai. Like the situation of Beijing, the rainfall has a little effect on the vegetable production. In recent years the huge financial capital has made tremendous investment in irrigation and water conservancy facilities, for which the amount of rainfall is no longer an important restricted factor in vegetable production in Shanghai. The impact of the proportion of agriculture value to GDP in Shanghai is relatively limited. This is closely related with the policy which launched in Shanghai in recent years, ensuring the local vegetables a certain "inventory". Although the secondary and tertiary industries are being rapidly developed, the process of industrialization and urbanization keep accelerating, the "inventory" policy to ensure a certain amount of vegetable growing areas has a positive effect on vegetable production in Shanghai. The main reasons that the total costs per unit, net profits per unit and the rural electrical power consumption have a lower correlation with Shanghai's vegetable production might be the similar with Beijing.

\section{Impact Analysis of Various Factors on the Capacity of Vegetable production in Hangzhou}

The respective grey correlation grade of every factor on Hangzhou vegetable outputs is shown in table 3. According the descending order, the order of the grey correlation grades between all factors and Hangzhou vegetable production is: yield per unit area $>$ total power of agricultural machinery $>$ vegetable sown areas $>$ average air temperature $>$ the effective irrigated areas $>$ the amount of fertilizer consumption $>$ sunshine hours $>$ the labor numbers per unit $>$ net profits per unit $>$ total costs per unit $>$ yearly rainfall $>$ electrical power consumption $>$ the proportion of agriculture value to GDP.

Specifically, first, vegetable sown areas and yield per unit area have higher grey correlation grade value on the vegetable output in Hangzhou. This result is in line with the actual situation, since these two factors are the most important factors to determine vegetable production. The total power of agricultural machinery has a greater impact on vegetables outputs in Hangzhou, indicating that high levels of agricultural machinery contribute to the increase in vegetable production. Second, the average air temperature has a higher correlation with vegetables yield in Hangzhou. Similar to Shanghai, the average air temperature maintained at around $17^{\circ} \mathrm{C}$ in the whole year, and it's common to growing vegetables in open field. In the event of extreme weather, the capacity of self-sufficient supply in Hangzhou will be largely affected. Third, the effective irrigated areas and fertilizer consumption, these technological factors, have a certain influence on the outputs of vegetables in Hangzhou. Fourth, the sunshine hours have a certain influence on the cultivation and outputs of vegetable in Hangzhou. Similar to Beijing and Shanghai, sunshine duration has a significant impact on the quality and yield of vegetables. Fifth, the labor numbers per unit affect the vegetable production in Hangzhou to a certain extent. Sufficient labor input is conducive to the improvement of vegetable production and vice versa. With the rapid development of non-agricultural industries in Hangzhou, a great number of human capitals pour into secondary and tertiary industries, as a result, the labor power engaged in vegetable production is decreasing both in quantity and in quality year by year. This is not conducive to the improvement vegetable production capability in Hangzhou.

Other factors such as total costs per unit, net profits per unit, yearly rainfall, rural electrical power consumption and the proportion of agriculture value to GDP have relatively limited influence on the vegetable production capability in Hangzhou. Similar with Beijing and Shanghai, the amount of rainfall has little effect on the vegetable production. In recent years the central and local financial capital have made tremendous investment in irrigation and water conservancy facilities, for which the amount of rainfall is no longer an important restricted factor in vegetable production in Hangzhou.

The reasons that the three factors, such as the total costs per unit, net profits per unit and rural power consumption have a lower correlation with Hangzhou's vegetable production might have a similar situation with Beijing and Shanghai. The impact of the proportion of agriculture value to GDP on the output of vegetables in Hangzhou is relatively small. It is also possibly related with the relevant local government policies. With the rapid development of the secondary and tertiary industries, the process of urbanization and industrialization keep accelerating, Hangzhou municipal government takes various measures to ensure the vegetables supply and other necessities meanwhile. For example Hangzhou founded the leaf vegetable production functional areas after the snowstorm in 2008, and established the price adjustment and compensation mechanisms of vegetables. These measures have a positive role on the stability and enhancement of vegetables production and selfsufficient supply capacity in Hangzhou. Now, vegetable self-sufficient supply rate achieved over $52 \%$ in the main part of Hangzhou city, and the self-sufficient sup-

\footnotetext{
According to Yin, the deputy director of Shanghai Municipal Agricultural Commission, the national average price of vegetables rose by $40 \%$ since 2010 , while Shanghai rose by only $20 \%$. The experience is to ensure a certain amount of local. The rate of self-supply of Shanghai vegetable achieved 55\% in 2010, and local leafy green vegetables accounted to 90\% of total supply. "The Second Five-Year" plan of Shanghai clearly stipulated that by 2020 Shanghai must ensure the self-grown vegetables achieved more than $30 \%$ of the total supply. Data from: Vegetable price increases, who is the promoter? , Liberation Daily, August 21, 2010, http://newspaper.jfdaily.com/ jfrb/html/2010-08/21/content_397179.htm.
} 
ply rate of leaf vegetables achieved over $72 \%{ }^{7}$.

\section{Comparative Analysis on the Influence Factors of Vegetable production of the three cities}

In order to clearly see the different influences of various factors on the three major cities' vegetable production, this part will compare the grey dynamic correlation grade results between these factors and the vegetables' production and self-sufficient supply capacity of the three major cities. As data in table 3 and figure 5 shows, the influences which have greater influence on all the three major cities' vegetable production mainly include: the sown areas of vegetables, total agricultural machinery power, effective irrigated areas, amount of fertilizer consumption, sunshine hours and the labor numbers per unit. These results indicate that for any metropolitan cities, to maintain a certain amount of vegetables' sown areas, high levels of agricultural machinery, effective irrigation capacity, reasonable amount of chemical fertilizer, a certain amount of sunshine hours and the necessary labor input, are essential conditions to improve urban capacities of vegetable production.

However, the following factors, such as yearly rainfall, rural electrical power consumption, the total costs and net profits per unit, have relatively lower influence on the capacities of the three major cities' vegetable production. The fact that the yearly rainfall factor has lower influence on vegetables' production illustrates the investments of the Chinese central and local governments in construction of the irrigation facilities played a positive role in recent years, and so as to the influence of the yearly rainfall on urban vegetables' production is declining. About the rural electrical power consumption factor, in the future related researches, the both data that the agricultural and the secondary and tertiary industries' electrical power consumption in the rural areas should be distinguished in the total rural electrical power consumption, so that the electrical power consumption factor might have a higher impact on vegetable production. As for the costs and profits per unit factors, the further analysis should be carried out based on new method thinking of lag factor and other factors.

The influences of the other three factors on vegetables' production are obviously different, such as average air temperature, yield per unit area and the proportion of agriculture value to GDP for the three metropolitan cities. These significant differences are basically consistent with the realities. For more detail, firstly, in terms of average air temperature, this factor has greater influence on vegetables' production of the two southern cities---Shanghai and Hangzhou, but it has less effect on the vegetables' production in Beijing. The average air temperature in Beijing as a northern city is low, so the planting patterns of greenhouse and facilities are more widespread and the impact of temperature changes is lower. While, since the average air temperature is higher, the way of open-air vegetable planting is more widespread than Beijing and the impact of temperature changes is higher for Shanghai and Hangzhou.

Secondly, in terms of the level of yield per unit area, this factor has greater influence on vegetables' production of Shanghai and Hangzhou, but it has less effect on the vegetables' production in Beijing. This difference is also in consistent with the reality. As to the level of yield per unit area, the level of Beijing's yield per unit area is much higher than those of Shanghai and Hangzhou, but as the capital city, the land resources in Beijing is extremely scarce. With the rapid development of Beijing' secondary and tertiary industries and the rapid process of urbanization and industrialization, a large number of human resources and material resources flocked from the first industry to the secondary and tertiary industries. However, in this process Beijing's government did not take effective policies measures in time to ensure a certain planting areas of vegetable and other resources ${ }^{8}$, which resulted in a sharp drop of Beijing's vegetable planting area and total outputs in recent years, and so as to the positive influence of the level of vegetables' yield per unit area is decreased on vegetable outputs in Beijing. At the same time, compared with Beijing, the other two major cities of Shanghai and Hangzhou took various effective measures to ensure a certain area of local vegetables' planting and self-sufficient supply rate. Based on a certain planting area of vegetables, the positive role of the level of vegetables' yield is prominent in Shanghai and Hangzhou.

Thirdly, in terms of the proportion of agriculture value to GDP, this factor has greater influence on vegetables' production in Beijing, but it has less effect on the vegetables' production of Shanghai and Hangzhou. This difference is still closely related to whether the local government positively took policies to ensure a stable local supply of vegetables or not. In recent years, with the rapid development of Beijing' secondary and tertiary industries and the rapid process of urbanization and industrialization, the countermeasures taken by Beijing government are not strong enough. Neither clear policies to ensure a certain area of vegetables nor positive policies to encourage human capital to be engaged in the industry of vegetables' planting were taken by Beijing government. Under the background of the expanding differences of comparative income, the planting areas of vegetables are shrinking and the human capital engaged in the industry of vegetables' planting is losing. This may be very negative impact on

\footnotetext{
Data resource: MO, F., Y. F. PAN 2011. Over Half of the Vegetable Consumption in Hangzhou City Produced in Local Field. Hangzhou Daily, Feb 19, 001.

${ }^{8}$ Now the related experts are investigating the vegetable market consumption, vegetable production facilities, existing agriculture productivity and vegetable industrial layout, etc., so as to they could finally determine the minimum amount of vegetable sown areas. However, the other two cities: Shanghai and Hangzhou have already taken a lot of policies and measures to ensure a certain area of vegetables. Compared with Shanghai and Hangzhou, there is a time delay for Beijing government to take effective policies and measures to ensure certain planting areas of vegetable and other resources.
} 


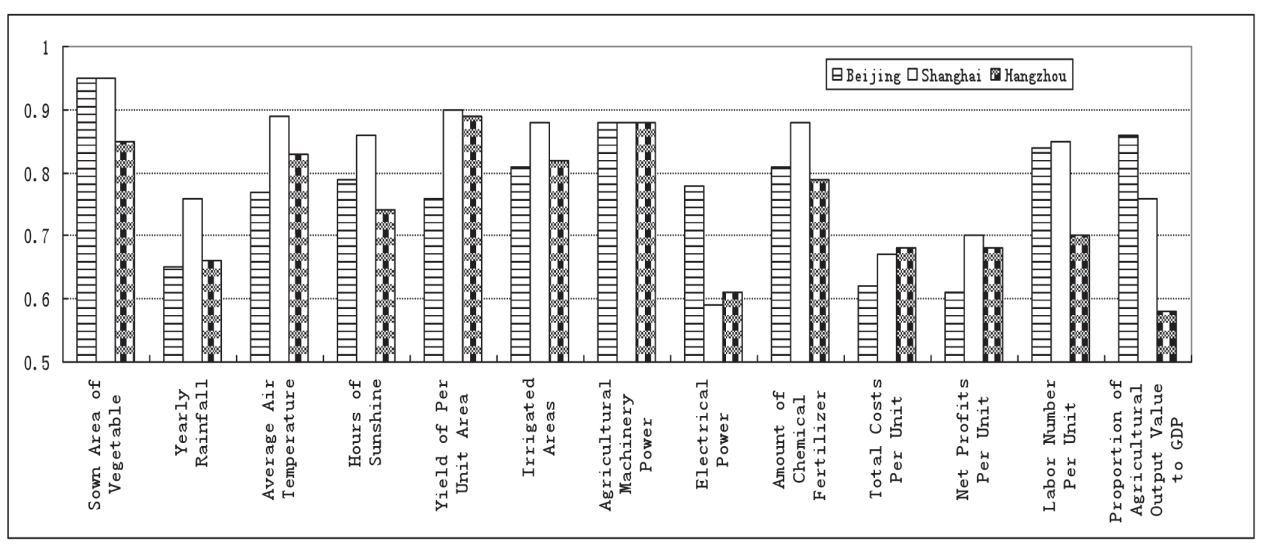

Fig. 5. Comparisons of the GCDA Results in the Three Major Cities Data sources: derived from Table 3

the capacities of Beijing's vegetable production. While, the other two major cities of Shanghai and Hangzhou took a number of effective measures to ensure a certain amount of land resources, human capital and other resources to remain in the field of vegetable industry. For example, According to Yin $\mathrm{Ou}$, the deputy director of Shanghai Municipal Agricultural Commission, the national average price of vegetables rose by $40 \%$ since 2010 , while Shanghai rose by only $20 \%$. The experience is to ensure a certain amount of local. The rate of selfsufficient supply of Shanghai vegetable achieved 55\% in 2010, and local leafy green vegetables accounted to $90 \%$ of total supply. "The Second Five-Year" plan of Shanghai clearly stipulated that by 2020 Shanghai must ensure the self-grown vegetables achieved more than 30\% of the total supply. ${ }^{9} \quad$ And for Hangzhou, the government set up municipal leaf vegetable production areas since 2008 after the snowstorm happened, and also established the mechanism of vegetable price adjustment and compensation, these policies and measures play great positive roles to stabilize and improve Hangzhou city's self-sufficient supply capacity. in 2011 the main urban area of Hangzhou city vegetable and self-sufficient rate to achieve $52 \%$ above, in which the leaf is self-sufficient rate of more than $72 \% .^{10}$ So relatively speaking, compared with Beijing, the urbanization, industrialization and the declining proportion of agriculture have a less negative influence on the vegetables' production and self-sufficient supply for Shanghai and Hangzhou.

\section{DISCUSSION}

\section{Tactics and Suggests}

It is shown from the aforesaid comparative analysis that guaranteeing the important factors, e.g. the vegetable sown areas, total power of agricultural machinery, effective irrigating areas, reasonable fertilizer consumption, and sufficient labor number, which have high impact on the vegetable production capability of the three megalopolis, is a prerequisite to enhance the vegetable production capability for the metropolitan cities in China.

Therefore, the first point is to ensure considerable vegetable sown areas, and pervade the bottom line mechanism of the vegetable planting acreage in other metropolitan cities in China. The second is to improve continuously the agricultural mechanization level, which is very meaningful for both vegetable production efficiency and transportation and circulation efficiency improvement. The third is to ensure effective irrigating areas. With the continuous amelioration of farmland irrigating infrastructure, the modern agriculture has gradually throw off the difficult weather-dependant problem, and convenient effective irrigating plays a significant role in enhancing urban vegetable production capability. So the irrigating infrastructure should be enhanced and ameliorated in the future to guarantee effective vegetable irrigating acreage. The fourth is to use fertilizer reasonably. The fertilizer is necessary in vegetable production and also is important for high and stable production. As well known, inadequate fertilizer impacts vegetable growth and then yield in vegetable production. Contrarily, excess fertilizer not only increases the production cost and is unprofitable for yield improvement, it also pollutes the environment and waste the resource. Therefore, in the vegetable production process, focusing on scientific planting and ensure reasonable fertilizer dosage plays a very important role in vegetable production, energy saving and pollution alleviation, and environment protection.

The fifth point is necessary human resource investment. The human resource investment is an important factor for agricultural production, and it plays an important role in improving agricultural production efficiency, farm produce guarantee, and sustainable development of agriculture. Relative research shows that the high

\footnotetext{
${ }^{9}$ Data resource: Vegetable price increases, who is the promoter?, Liberation Daily, August 21, 2010, http://newspaper.jfdaily.com/jfrb/ html/2010-08/21/content_397179.htm.

${ }^{10}$ Date resource: MO, F., Y. F. PAN 2011. Over Half of the Vegetable Consumption in Hangzhou City Produced in Local Field. Hangzhou Daily, Feb 19, 001.
} 
quality human resources have flowed to the second and third industries, and the human resources in agricultural production are in lower level, mainly women and the elder engaged in agricultural production. This situation is not conducive to the efficiency improvement of agricultural production. So it will be great benefit for the efficiency improvement of vegetable production and the supply safety of vegetable quantity and quality to increase the human resource investment in the vegetable industry and enhance education and training for vegetable planting farmers.

Different cities have their own characteristics. Beijing government should put Shanghai and Hangzhou for reference and learn from them, and make greater efforts in ensuring considerable vegetable planting areas and enhance vegetable storage mechanism. Shanghai and Hangzhou should use for reference the vegetable planting technology of Beijing and make effort to improve vegetable unit yield.

\section{Main Limitation and Future Research}

As we mentioned earlier, the government policy factors such as government subsidies and price supporting, etc. are not analyzed in the paper for lack of accurate data, which is a big drawback. We expect to obtain valid corresponding data through future survey for the further researches.

\section{REFERENCES}

Chen, Y. S., J. Qiao and F. Z. Yan 2009 An empirical analysis on farmers' willingness of producing pollution-fee certified vegetables-Beijing as a case study. Issues in Agricultural Economy, 6: 34-39 (in Chinese)

Deng, J. L. 1982 Control problems of grey system. Systems and Control Letters, 1: 288-294

Deng, J. L. 1989 Introduction to grey system theory. The Journal of Grey System, 1(1): 1-24

Feng, S. Y. 2004 Factor analysis of the development of vegetable industry in Shandong province. Master Degree Thesis of Nanjing Agricultural University (in Chinese)

Hamzacebi, C. and M. Pekkaya 2011 Determining of stock investments with grey relational analysis. Expert Systems with Applications, 38: 9186-9195

Huang, Z. R. et al. 2007 Application of grey correlative degree analysis relation of main quantitative characters and output in eleven new sugarcane varieties. Chinese Agricultural Science Bulletin, Vol. 23(12): 198-201 (in Chinese)

Kou, P. J. 2004 Organization pattern of Beijing's fruit and vegetable market. $\mathrm{PhD}$ thesis of China Agricultural University (in Chinese)

Li, C. J. 2006 Study of exports-growth factors of Chinese vegetables to Japan. Master Degree Thesis of Nanjing Agricultural University (in Chinese)

Li, C. Y. and D. Y. Zhou 2009 Food safety control and organizational modes of vegetable supply chain. Ecological Economy, 12: 117-120 (in Chinese)

Li, S. P. 2006 Vegetable industry in China: economic analysis and policy options. PhD Thesis of Chinese Academy of Agricultural Sciences (in Chinese)

Lin, Y. Y. 2003 grey relationship degree analysis between the market orientation and the senior management. Management Sciences in China, 16(3): 61-65 (in Chinese)

Liu, H. Y. 2005 The international competitiveness of China's vege- table industry. Master Degree Thesis of Dongbei University of Finance and Economics (in Chinese)

Lu, H. L. et al. 2009 The role of Guanxi networks in vegetable supply chains: empirical evidence from P. R. China. Journal of International Food \& Agribusiness Marketing, 21: 98-115

Lu, I. J., S. J. Lin, and C. Lewis 2008 Grey relation analysis of motor vehicular energy consumption in Taiwan. Energy Policy 36: 2556-2561

Lu, Z. H. 2008 Study on vegetable productive profit and its influencing elements. PhD Thesis of Nanjing Agricultural University (in Chinese)

Morita, H. et al. 1996 Interval prediction of annual maximum demand using grey dynamic model. Electrical Power \& Energy systems, 18: 409-413

Pan, F. J. and Y. Y Mu 2010 Analysis of the impact factors and trends of vegetable price fluctuation in Beijing. Agricultural Outlook, 8: 24-28 (in Chinese)

Shao, Z. Y. 2009 A research on vegetable supply chain construction in Beijing. Master Degree Thesis of Beijing Jiaotong University (in Chinese)

Sun, X. X., A. Mitra, and P. G. Cao 2007 Grey correlative degree analysis on factors of small \& medium-sized enterprise marketing mix. Journal of Wuhan University of Technology, 29(6): 143-146 (in Chinese)

Wang, B. Q. et al. 2010 Correlation and grey relation analysis between agronomic traits for yield of sweet potato in regional trails of North China. Journal of Qingdao Agricultural University (Natural Science), 27(4): 296-299 (in Chinese)

Wang W. J. 2007 Research on the development and competitivity of vegetable industry in Shandong province. Master Degree Thesis of Shandong University (in Chinese)

Wang, X. Y. 2004 Study on the vegetable production, consumption and trade in China, Master Degree Thesis of Huazhong Agricultural University (in Chinese)

Wu, C. L., J. Yang, and M. J. Li 2010 The price of vegetables is rising, who is the promoter? Liberation Daily, http://newspaper.jfdaily.com/jfrb/html/2010-08/21/content_397179.htm (in Chinese)

Wu, Y. Z. 2009 The research on performance estimation of vegetable supply chain in Beijing. Master Degree Thesis of Beijing Jiaotong University (in Chinese)

Xiao, C. X. 2007 Studies on the production, trade and policy of vegetable industry in China, $\mathrm{PhD}$ Thesis of Huazhong Agricultural University (in Chinese)

Yang, S. J. 2004 Studies on the development of vegetable industry in China. PhD Thesis of Huazhong Agricultural University (in Chinese)

Yang, W. M. 2006 Research on structure optimization of Chinese vegetable supply chain, $\mathrm{PhD}$ Thesis of Chinese Academy of Agricultural Sciences (in Chinese)

Zang, J. 2009 Research on strategic cost management of Beijing vegetable supply and marketing chain. Master Degree Thesis of Beijing Jiaotong University

Zhao, J. X. and Z. G. Zhang 2008 Analysis on the influence factors of farmers planting safe vegetables. Academic Journal of University of International Business and Economics, 2 52-57 (in Chinese)

Zhao, R. 2009 Research on vegetable supply security in Beijing, Master Degree Thesis of Beijing Jiaotong University (in Chinese)

ZHAO, X, Y. M. Duan and X. Zhang 2011 Performance evaluation on China's public fiscal expenditures: based on the perspectives of both fairness and efficiency. Journal of Chinese Academy of Governance, 1: 88-93 (In Chinese)

Zhao, Y. S. and A. P. Zhao 2010 Construction of Beijing agricultural products market information system and its development. Food and Nutrition in China, 4: 39-42 (in Chinese)

Zheng, H. Q. 2005 Study on the problems of the vegetables export trade in Shandong province, Master Degree Thesis of Sichuan Agricultural University (in Chinese) 